
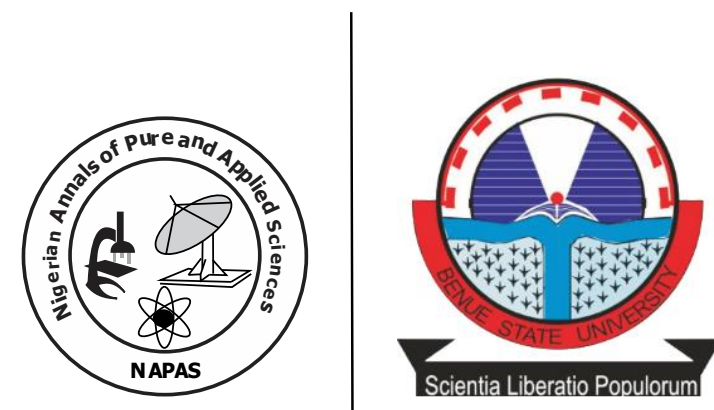

\title{
Surveys of Gastrointestinal Parasites of Sus scrofa domesticus (Domestic Pig) in Ushongo Local Government Area, Benue State, Nigeria.
}

*1Yaji, A.D., ${ }^{1}$ Fayum, K.T. and ${ }^{20}$ nah, I.E.

*1Department of Biological Sciences, Benue State University, Makurdi Benue State Nigeria

2Department of Medical Laboratory Science, Federal College of Veterinary and Medical Laboratory Technology, Vom-Jos, Plateau state, Nigeria

Corresponding author: *asooyaji@gmail.com

\begin{abstract}
Gastrointestinal parasites are responsible for substantial loss of productivity in livestock production. This study was carried out with the aim of determining the prevalence of gastrointestinal parasites of pigs in Ushongo LGA of Benue State, Nigeria over a period of three months Four hundred fecal samples were collected from the rectum of pigs and screened using the simple tube floatation and tube sedimentation techniques. An overall prevalence of $33.5 \%$ was observed. A total of 9 parasite species were isolated. Ascaris, Fasciola, Taenia solium, Trichuris suis, Hymenolepsis, Isospora suis, Strongyloides, Eimeria Spp and Hookworm had a prevalence of 24.17\%,16.48\%, 19.78\%, 6.59\%, $1.09 \%, 3.29 \%, 18.69 \%, 6.59 \%, 3.29 \%$ respectively. This study reveals that gastrointestinal parasites are relatively low in Ushongo L.G.A. Further investigation should be carried out to study the impact of parasitic infestation of pigs on public health in the study area.
\end{abstract}

Keywords: Gastrointestinal, Parasites, Ushongo, Ascaris, public health. 


\section{Introduction}

Pigs are among the abundant livestock potential in Nigeria at large and Benue state in particular (Aiyedun, 2014). Swine production forms an integral part of the rural economy in many parts of the world by providing an additional animal protein source for human consumption, generating employment and hence reducing poverty (Akanni et al., 2017).

Gastrointestinal parasites source their food from the contents of the gastrointestinal tract in which they live by arraying themselves to the intestinal wall (Edungbola and Obi, 1992). These parasites are responsible for substantial loss of productivity in the livestock industry (Agumah et al., 2015). They affect swine performance in terms of efficient feed conversion, poor growth rate, reduced gain and condemnation of affected organs after slaughter (Nsoso et al., 2000).They are known to deteriorate the wellbeing of pigs by robbing them of the essential nutrients that are required for optimum reproduction and productivity. They also injure some vital organs which play key role in the metabolic activities and assimilation process. The consequences of these activities are anorexia, poor growth rate, emaciation, infertility among others (Karaye et al., 2016).

Pigs heavily parasitized are more susceptible to diseases, the resulting diseases being the major causes of zoonosis. The two major groups of parasites which affect the gastrointestinal tract of pigs are basically helminthes and protozoans. The helminthes which includes nematodes, trematodes as well as some of the intestinal protozoans can be transferred to man thereby posing a high risk for the producer as well as consumer (Akanni et al., 2017).
There has been an unprecedented increase in pork consumption in Ushongo, a rural community in Benue state, Nigeria, as well as families resorting to raising pigs for subsistence and commercial purposes. With limited information on the risk factors and health benefits involved.

Although works have been done on the gastrointestinal parasites of pigs in other parts of Nigeria (Wosu, 2015; Pam et al., 2013; Okoroafor, 2014; Karaye et al., 2016, Sowemimo, 2013), few have been reported from Benue state (Omudu et al.,2006) and Ushongo L.G.A in particular.

The need for constant surveillance and monitoring to determine the gastrointestinal parasites status of animals cannot be overemphasized. This study was therefore, designed to investigate the prevalence of gastrointestinal parasites of pigs in Ushongo L.G.A. of Benue State of Nigeria.

\section{Materials and Methods.}

\section{Study Area}

This study was carried out in Ushongo local government area of Benue state, Northcentral Nigeria. Ushongo is situated between latitiude $7^{\circ} 15^{\prime} 0^{\prime \prime} \mathrm{N}$ and longitude $8^{\circ} 40^{\prime} 0^{\prime \prime} \mathrm{E}$ and has 11 council wards with Lessel as its headquarters. The study was conducted in four council wards: Mbakuha, Mbayegh, Mbaaka and Lessel township of Ushongo L.G.A.

\section{Sample Collection}

With the assistance of the pig owners, fecal samples were collected from the rectum of 400 pigs from four different locations of Mbakuha, Mbayegh, Mbaaka and Lessel of Ushngo L.G.A. The age, sex and breed of the pigs were noted. The samples were collected from the pig's farms. 


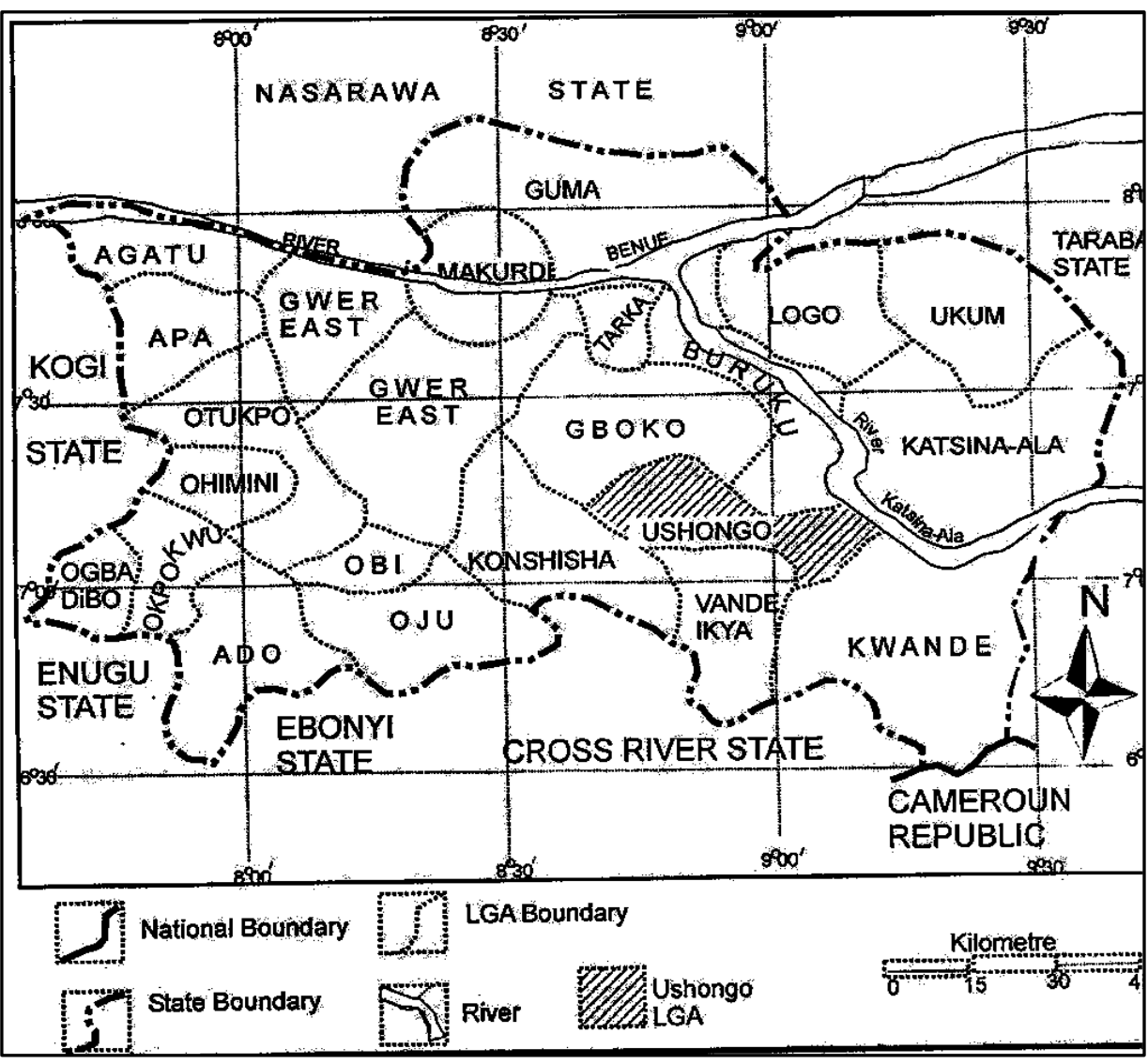

Figure 1: Map of Benue State Showing Ushongo Local Government Area

Source: Ministry of Land and Survey, Makurdi.

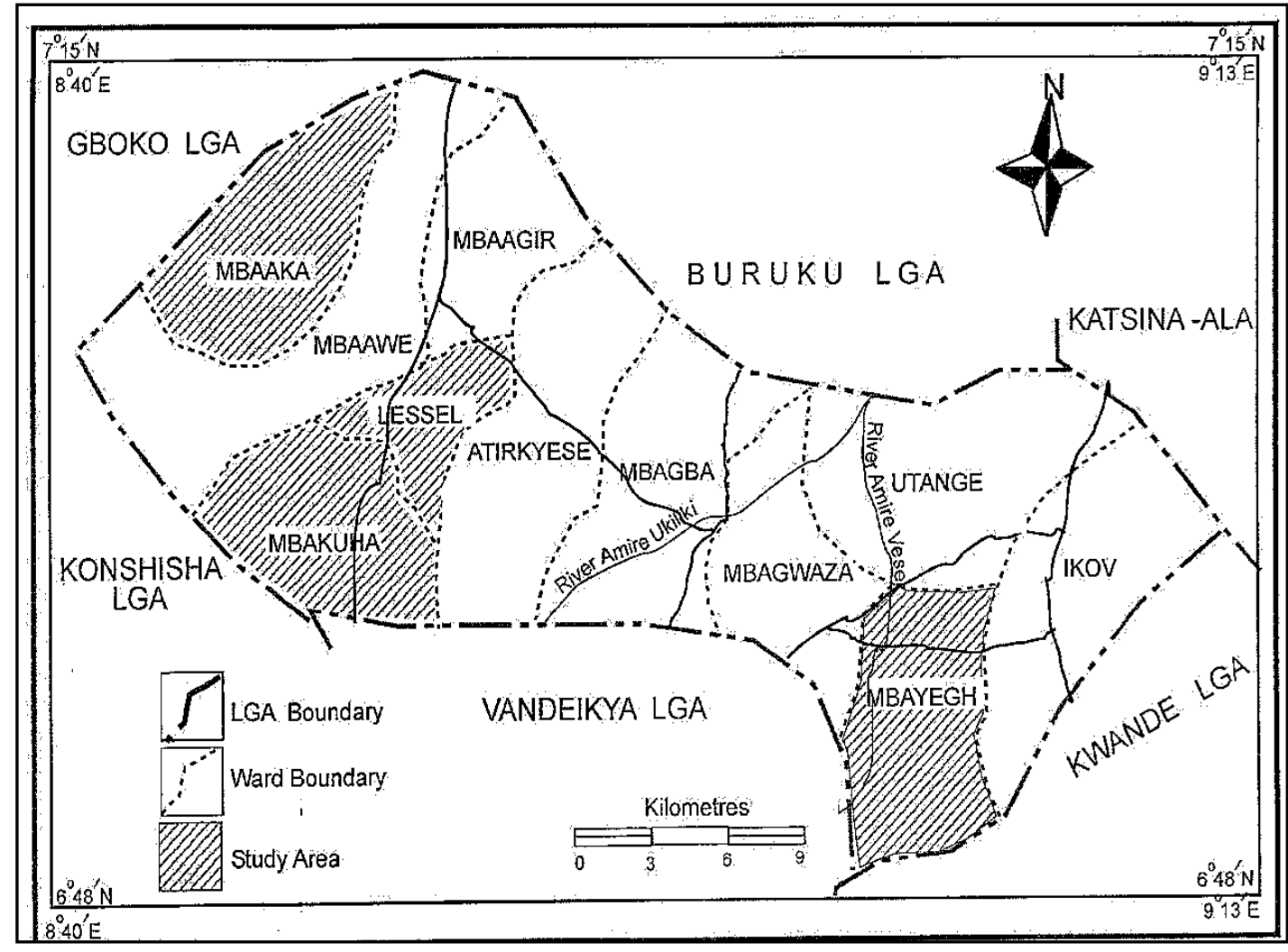

Figure 2: Map of Ushongo Local Government Area Showing Sampling Areas.

Source: Ministry of Land and Survey, Makurdi.

\section{Faecal Sample Collection}

The animal to be examined was restrained by hand, a rectum loop was then lubricated and gently inserted into the rectum to collect the fecal material. It was ensured that the loop was clean and sterilized by heating before using on a different animal. 
52| Surveys of Gastrointestinal Parasites of Sus scrofa domesticus (Domestic Pig) in Ushongo ...

\section{Parasitological Examination of Faecal Sample}

Faecal samples were taken directly into specimen bottles and preserved with $10 \%$ formalin. An estimated $3 \mathrm{~g}$ of faeces was emulsified using an applicator stick in $50 \mathrm{ml}$ of floatation fluid (sugar solution) contained in a beaker. The emulsified faeces were sieved and suspension collected in another beaker and transferred into the test tube, covered with a cover slip and allowed to stay in the rack. The tube with suspension was gently filled with floatation fluid; leaving a convex meniscus at the top of the tube and allowed to stand for 20 minutes. The cover slip was lifted carefully from tube together with the drop of fluid adhered to it and placed on the microscope slide gently avoiding air bubbles. The prepared slide was examined microscopically using 10x objectives with condenser iris closed sufficiently to give a good contrast. The 40x objective was used to examine parasites ova. The number of each species of parasite ova and cysts on the microscope was viewed and counted.

\section{Statistical Analysis}

Data generated were entered into a computer software; Statistical Package for Social Sciences (SPSS version 20.0) and was analyzed using Chi-square test. Proportions were compared and $\mathrm{P}$ values less than or equal to $0.05(\leq 0.05)$ were considered statistically significant.

\section{Results}

The overall prevalence of gastrointestinal parasites in this study was found to be $33.5 \%$ among the pigs sampled. Mbakuha and township wards recorded the highest and least prevalence of $56.0 \%$ and $22.0 \%$ respectively. There was significant difference in the rate of infection among the four selected council wards $(\mathrm{P}<0.05)$ (Table 1). Male pigs were more infected (39.6\%), compared to the female $(28.4 \%)$. There was significant difference in the rate of gastrointestinal parasitic infection among the male and female pigs from four council wards $(\mathrm{P}<0.05)$. Higher infection occurred among the adult pigs $(37.5 \%)$ compared to the younger ones $(29.5 \%)$, although there was no significant difference in the rate of gastrointestinal parasitic infection among them $(\mathrm{P}>0.05)$ (Table 2).

The Local breeds were more infected 78 $(37.5 \%)$ compared to the exotic breeds 56 $(29.2 \%)$. There was no significant difference in the rate of infection among the different breeds $(\mathrm{P}>0.05)$ (Table 3$) .67 .0 \%$ of the pigs had no infestation, while $19.0 \%$ and $14.0 \%$ had single and double infestations respectively (Table 4). More species of the parasites (9) were recovered from Mbayegh council ward while 7 species were recorded in township. Mbakuha and Mbaaka council wards recorded 5 each (Table 5).A. suum had the highest frequency $44(24.17 \%$ ) while hook worm recorded the least 6(3.29\%) (Table 6).

Table 1: Prevalence of Gastrointestinal parasites of pigs from four council wards in Ushongo L.G.A of Benue State.

\begin{tabular}{lccc}
\hline Council Wards & No. Examined & No. positive & Prevalence $(\%)$ \\
\hline MbaKuha & 100 & 56 & 56.0 \\
Mbaaka & 100 & 24 & 24.0 \\
Township & 100 & 22 & 22.0 \\
Mbayegh & 100 & 32 & 32.0 \\
Total & 400 & 134 & 33.5 \\
\hline
\end{tabular}

$\left(\chi^{2}=38.85 ; \mathrm{df}=3 ; \mathrm{P}=0.00\right)$ 
Table 2: Prevalence of Gastrointestinal parasites of pigs in Ushongo L.G.A. in relation to sex and age.

\begin{tabular}{llll}
\hline Sex & No. Examined & No. positive & Prevalence $(\%)$ \\
\hline Male & 182 & 72 & 39.6 \\
Female & 218 & 62 & 28.4 \\
Age & & & \\
\hline Adult & 224 & 84 & 37.5 \\
Young & $17 * 6$ & 50 & 29.5 \\
Total & $\mathbf{4 0 0}$ & $\mathbf{1 3 4}$ & \\
\hline$\left(\chi^{2}=8.301 ; \mathrm{df}=1 ; \mathrm{P}=0.016\right.$ for sex, and $\chi^{2}=4.75 ; \mathrm{df}=1 ; \mathrm{P}=0.093$ for age $)$
\end{tabular}

Table 3: Prevalence of Gastrointestinal parasites of pigs in Ushongo L.G.A in relation to the breed of pigs.

\begin{tabular}{llll}
\hline Breed & No. Examined & No. positive & Prevalence $(\%)$ \\
\hline Local & 208 & 78 & 37.5 \\
Exotic & 192 & 56 & 29.2 \\
Total & 400 & 134 & 33.5 \\
\hline
\end{tabular}

$\left(\chi^{2}=5.04 ; \mathrm{df}=1 ; \mathrm{P}=0.080\right)$

Table 4: Parasitic load of gastrointestinal parasites of Pigs in Ushongo L.G.A of Benue State.

\begin{tabular}{lc}
\hline Parasite load & $(\%)$ \\
\hline No infection & $168(67.0)$ \\
Single infection & $76(19.0)$ \\
Double infection & $56(14.0)$ \\
\hline
\end{tabular}

Table 5: Species of gastrointestinal parasites isolated from pigs in four council wards of Ushongo LGA of Benue State.

\begin{tabular}{lllll}
\hline S/N & MBA KUHA & MBAAKA & TOWNSHIP & MBAYEGH \\
\hline 1. & Ascaris $\mathrm{spp}$ & Ascarissp & Eimeria $\mathrm{spp}$ & Taenia $\mathrm{spp}$ \\
2. & Taenia $\mathrm{spp}$ & Strongyl $\mathrm{spp}$ & Ascaris $\mathrm{spp}$ & Strongyl $\mathrm{spp}$ \\
3. & Hymenolepsis spp & Taeniaspp & Strongyl $\mathrm{spp}$ & Eimeria spp \\
4. & Strongyl $\mathrm{spp}$ & Eimeriaspp & Taenia $\mathrm{spp}$ & Faciola \\
5. & Eimeria $\mathrm{spp}$ & Hookworm & Faciola & Eimeria $\mathrm{spp}$ \\
6. & & & Trichuris & Ascaris $\mathrm{spp}$ \\
7. & & & Hookworm & Trichuris \\
8. & & & & Isospora \\
9. & & & Hookworm \\
\hline
\end{tabular}

Table 6: Percentage prevalence of individual parasites

$\begin{array}{lll}\text { Parasites } & \text { Frequency } & \text { Percentage (\%) } \\ \text { Ascarissuum } & 44 & 24.17 \\ \text { Faciola } & 30 & 16.48 \\ \text { Taenia Solium } & 36 & 19.78 \\ \text { Trichurissuis } & 12 & 6.59 \\ \text { Hymenolepsis spp } & 2 & 1.09 \\ \text { Isosporasuis } & 6 & 3.29 \\ \text { Strongyloides } & 34 & 18.69 \\ \text { Eimeria } \text { spp } & 12 & 6.59 \\ \text { Hook worm } & 6 & 3.29 \\ \text { Total } & 182 & 100.0\end{array}$





\section{Discussion}

The overall prevalence of gastrointestinal parasites of pigs in Ushongo as observed in this study was $33.5 \%$. Other works across Nigeria such as Sowemino et al., (2012), Pam et al., (2013), Okoroafor, 2014, and Akanni et al., (2017) have also reported gastrointestinal parasitic infection in swine. This prevalence is relatively low as compared to other survey in various locations across Nigeria and Africa. Aiyedun (2014) in Kwara, Nigeria recorded a very high prevalence of $100 \%$. Karaye et al., (2016) recorded $61.5 \%$ across 4 LGAs in Nasarawa state, Nigeria. Atawana et al., (2016) recorded $56 \%$ in Ejisu municipality in Ghana.

The relatively low prevalence observed in this study may be due to effective management systems adopted by the local farmers. Statistical analysis shows a significant difference between male and female pigs. This agrees with studies by Omudu et al., (2006) in Makurdi, Okoroafor et al., (2014) Sowemimo et al., (2012) and Wosu (2015), where male pigs were more infected. But this disagrees with the works of Atawana et al. (2015) where female pigs had higher prevalence than males. He attributed his findings to the fact that female pigs are kept longer than males and are immune suppressed during pregnancy and lactation. The high prevalence among the males could be as a result of their high scavenging rate at the various locations.

A higher prevalence was observed among the adults. Although this result was statistically not significant which proves that both adult and young pigs have equal chances of obtaining a higher parasite load. The result disagrees with that of Pam et al., (2013) where younger pigs were insignificantly more infested than the adults. He attributed it to low immunity in young than adults.

This survey also reveals a higher prevalence in relation to breed of local and exotic with the prevalence of $37.5 \%$ and $29.2 \%$ respectively. Although not statistically significant, it agrees with that of Aiyedun (2014) who also reported a similar result.

The survey reveals 8 different parasite species across the four sample locations with the helminthes occurring the most. This conforms with the works of Sowemimo et al., (2012), Omudu et al., 2006, Agumah et al.,(2015) and Karaye et al., (2016) where helminthes parasites all recorded a higher prevalence as compared to protozoan parasites.

The prevalence of parasites in relation to location shows Mbakuha with the highest rate (56.0\%) while township has the least with $22.0 \%$ prevalence. This may be attribute to the better management strategies adopted by the farmers of the township region as most pigs were intensively reared as compared to higher scavenging pigs of the Mbakuma region which were more prone to parasites infestation. This agrees with the work of Wosu (2015) who recorded a low prevalence of $24.10 \%$ in intensively managed pigs in Nsuka South East Nigeria as well as Aiyedun (2014) with a high prevalence of $100 \%$ in the scavenging pigs of Kwara state.

The predominant parasites species encountered (Ascarissuum, Stronglyl spp, Taenia solium and Fasciola) seem to be endemic in Nigeria as they feature consistently in previous studies (Omudu et al. 2006; Wosu, 2015; Karaye et al. 2016; and Sowemimo, 2012).

\section{Conclusion}

The study shows that $33.5 \%$ prevalence is relatively low and that gastrointestinal parasites are mild in Ushongo L.G.A. It also shows slightly high prevalence in males $(39.6 \%)$ than females (28.4\%).This work also shows that Ascaris spp. And Taenia Spp where the most common pig parasite encountered in Ushongo. The occurrence this large spectrum of parasite species (especially Faciola, Ascaris and Hookworm) raises the concern about their zoonotic implications. In a community where pigs are reared and pork consumed by a large part of the population. The transmission cannot be ruled out. The public health implication of this development should not be over looked. Hence a further investigation into the possible impact of parasitic infestation of pigs on public health in Ushongo L.G.A. The extensive or scavenging pig systems should be 
discouraged and the animal husbandry system should be encouraged.

\section{Photomicrograph of Intestinal parasites of pigs Identified}

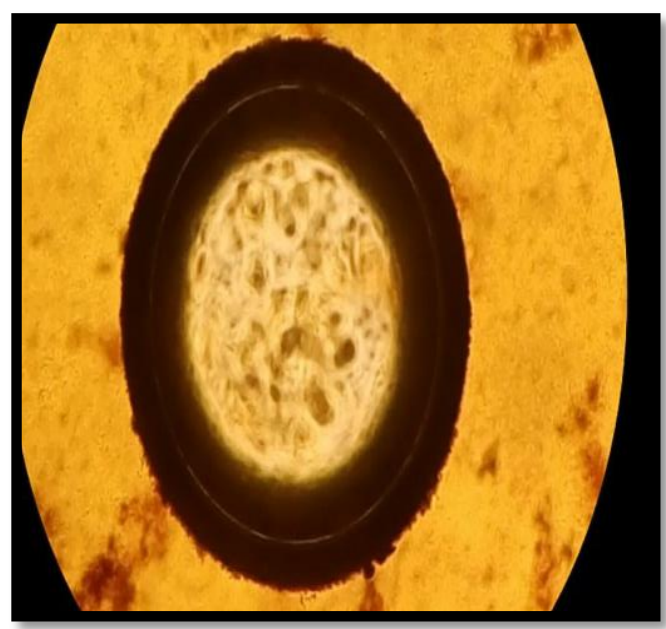

Plate 1: Ova of Taenia

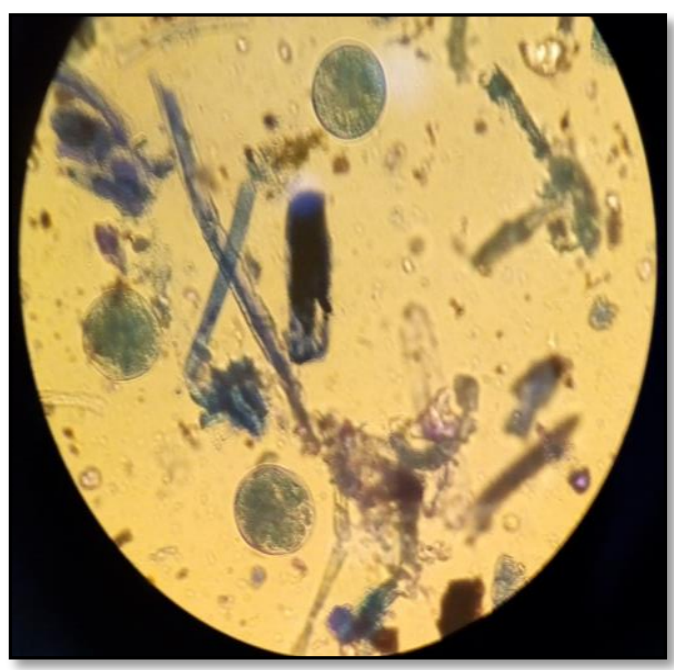

Plate 2: Cyst of Isosporasuis

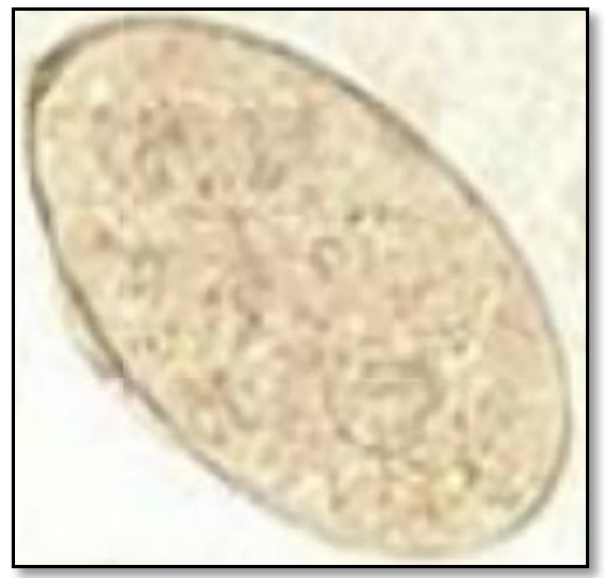

Plate 5: Ova of Ascaris suum

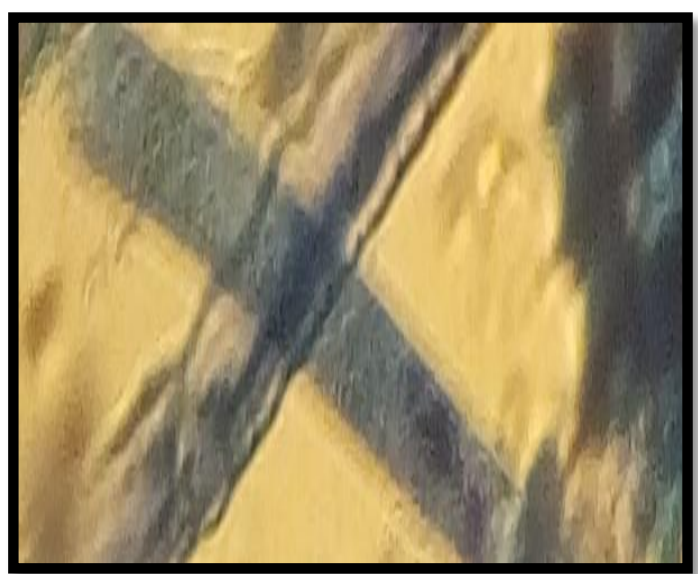

Plate 2: Larvae of Strongyloides

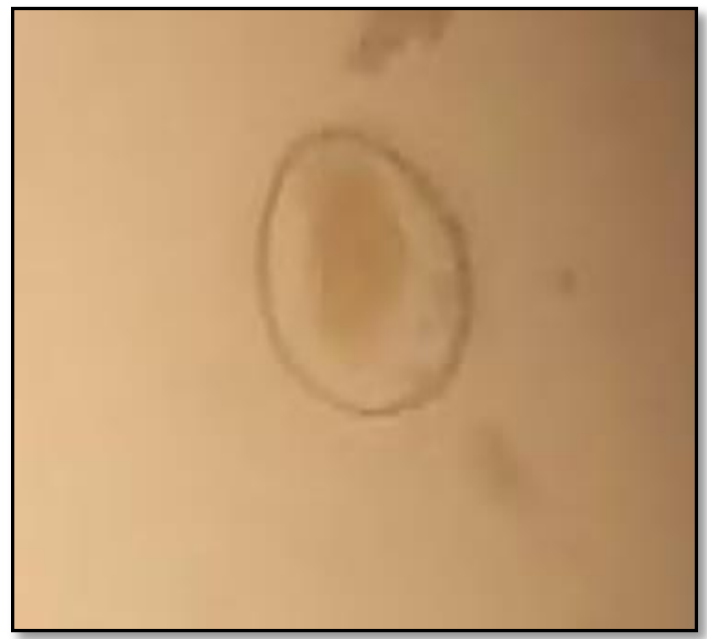

Plate 4: Cyst of Eimeria

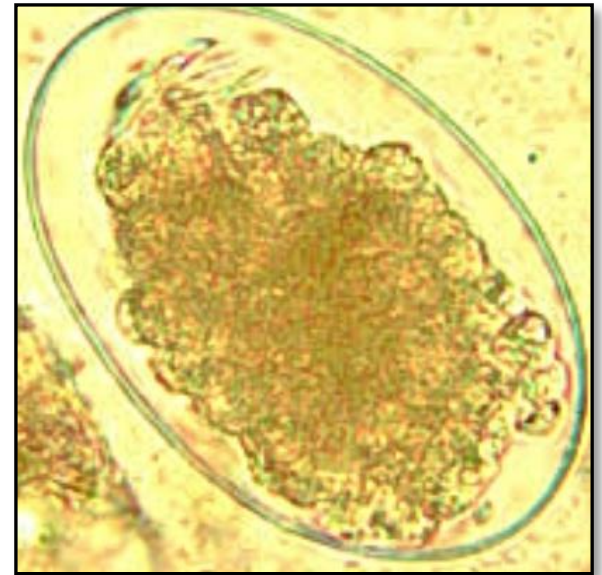

Plate 6: Ova of hookworm 
56| Surveys of Gastrointestinal Parasites of Sus scrofa domesticus (Domestic Pig) in Ushongo ...

\section{References}

Agumah, N., Daminabo, V., Ekam, E., Okonkwo, E., Nwuzo, A., Afiukwa, F., and Agah, M. (2015). Prevalence of intestinal parasites in Faecal droppings of swine in Pankshin Urban, Pankshin local government area, Plateau state, Nigeria. American Journal of Life Sciences 3(2): 119-122.

Akanni, O., Kingsley, C., Migap, C., and Jatau, J., (2017). Prevalence of Gastrointestinal parasite of pigs in Jos south, local government area of Plateau state, Nigeria. Haya: Saudi Journal of Lifescience 2(5):140-142

Aiyedun J.O (2014). Public Health Implication of Gastrointestinal Parasites of Pigs in Kwara State, Nigeria. Journal of Animal and Veterinary Advances 13:783-785

Atawana, J., Arron-Korokn, V., Folirse, R., and Amenakpor, C. (2016). Prevalence of gastro intestinal parasites among pigs in the Ejisu Mumicipacity of Ghana. Scholars Journal of Agriculture and Veterinary Sciences, 3(1): 33-36.

Edungbola, L., and Obi, A. (1992) A Review of Human Intestinal Parasites in Nigeria, Challenges and Prospects for Integrated Control. The Nigerian Journal of Parasitology, 13: 27-37.

Karaye, G., Dogo, A., Iliyasu, D., and Madu, H. (2016). Prevalence on swine gastro intestinal parasites in four selected local government areas of Nassarawa state, Nigeria. International Journal of Livestock Research, 6(1): 21-26.
Nsoso, S., Mosala, K. Ndebele, R., and Remaju, S. (2000) The prevalence of internal and external parasites in pigs of different ages and sexes in South east District, Botswana. On desterpoort Journal of Veterinary Research, 67(3): 217-220.

Okorafor U., Unigwe, C., Okorafor, J., Isegbe, E., Ogbu, U., and Atoyebi, J. (2014). A survey of gastrointestinal parasites of pigs that arrived for slaughter at Bodija, abattoir, Idadan Oyo State, Nigeria. International Journal of Pure Applied Science Technology, 20(2): 53-57.

Omudu, E., Amuta, E., and Tse, D. (2006). Intestinal Helminthes of Urban Pigs with Notes on Public Health Implication. Journal of Pest Disease and Vector Management, 7: 424-429.

Pam,V., Ogbu, K., Batta, S., Obacisa, A., Akut, K., and Hassan, A. (2013). An investigation of Haemo and gastro intestinal parasites of pigs in some parts of langtang North local government area of Plateau state. Journal of Engineering, 3(11): 10-14.

Sowemimo, O., Asaoli, S., Adegoke, F., and Ayanmiyi, O. (2012). Epidemiological survey of gastro intestinal parasites of pigs in Ibadan, southwest Nigeria. Journal of Public Health Epidemiology, 4 (10): 294-298.

Wosu, M. (2015). Prevalence of internal parasites of intensively managed pigs located in Nsuka, South East Nigeria. Journal of Veterinary Advances, 5(6): 976-979. 